\title{
JIMMBA
}

\section{Pengaruh Partisipasi Anggaran, Kapasitas Individu, Self Esteem dan Kejelasan Sasaran Anggaran Terhadap Senjangan Anggaran Desa di Kecamatan Petanahan}

\author{
Sulis Nafisatun Khasanah ${ }^{1}$, Ika Neni Kristanti ${ }^{2}$ \\ ${ }^{1}$ Sekolah Tinggi Ilmu Ekonomi Putra Bangsa \\ ${ }^{2}$ Sekolah Tinggi Ilmu Ekonomi Putra Bangsa \\ Email: sulisnafisatunkhasanah3@gmail.com
}

\section{ARTICLE INFO}

Article History:

Received: March 13 2020

Accepted: March 14th 2020

Published: June 30th 2020

Keywords:

Budgetary Slack, Budget

Participation, Individual

Capacity, Self Esteem,

Budget Clarity

\begin{abstract}
This study aimed to examine the effect of budgetary participation, individual capacity, self esteem and clarity of budget targets on village budgetary slack that occurs in Petanahan District. This research was carried out in 21 villages in Petanahan Subdistrict. The sample in this study were 43 respondents who participated in the budgeting process. Data collection was done by distributing questionnaires directly to respondents. The analysis technique used was multiple linear regression analysis. The results of this study indicate that: (1) budgetary participation has a positive and significant effect on budgetary slack, (2) individual capacity has no effect on budgetary slack, (3) self-esteem has no effect on budgetary slack, (4) clarity of budget targets has a positive effect and significant to budgetary slack.
\end{abstract}

\section{Pendahuluan}

Sejak diberlakukannya otonomi daerah, desa diberikan kewenangan untuk mengurus sendiri pemerintahannya. Kewenangan yang dimiliki oleh desa diatur dalam Permendesa Nomor 1 Tahun 2015 yaitu desa memiliki kewenangan yang meliputi kewenangan dalam bidang penyelenggaraan pemerintahan desa, pembinaan kemasyarakatan desa, dan pemberdayaan masyarakat desa berdasarkan prakarsa masyarakat, hak asal usul, dan adat istiadat desa. Penyelenggaraan pemerintah desa dipimpin oleh kepala desa dan dibantu oleh aparatur desa. Berlakunya Undang-undang Nomor 6 Tahun 2014 tentang desa, menyatakan bahwa kepala desa dalam melaksanakan tugasnya harus mengelola keuangan dan aset desa dengan akuntabel, transparan, profesional, efektif dan efisien, bersih, serta bebas dari korupsi, kolusi, dan nepotisme. Pengelolaan keuangan desa dilakukan dengan proses penganggaran. anggaran merupakan salah satu proses penting dalam pengelolaan keuangan pemerintah, hal ini dikarenakan anggaran merupakan alat untuk mengukur kemampuan pemerintah dalam melaksanakan berbagai urusan yang menjadi wewenangnya dan faktorfaktor yang berpengaruh terhadap anggaran tersebut. Mardiasmo (2018:12) menyatakan bahwa anggaran daerah merupakan rencana kerja pemerintah daerah yang dinyatakan 
dalam bentuk uang (rupiah) dalam satu periode tertentu. Penyusunan anggaran pada organisasi sektor publik dikategorikan sebagai sebuah proses yang tergolong cukup rumit, hal ini dikarenakan anggaran pada sektor publik bukan hanya memuat rencana tahunan saja, namun juga merupakan suatu bentuk akuntabilitas dan transparansi atas pengelolaan publik yang dibebankan kepada pihak pemerintah daerah.

Anggaran mempunyai dampak langsung terhadap perilaku individu yang menyusun. Banyaknya pihak yang terlibat dalam proses penyusunan anggaran menyebabkan rawan terjadinya senjangan anggaran. Dunk dan Parera (1997) dalam Mardiasmo (2018:224) menyatakan bahwa senjangan anggaran merupakan perbedaan antara jumlah yang dianggarkan, realisasi biaya dan pengeluaran. Senjangan dalam anggaran terjadi apabila realisasi pendapatan cenderung melebihi target yang ditetapkan dari anggaran dan realisasi belanja cenderung dibawah target yang ditetapkan.

Pada tahap penyusunan anggaran, terdapat faktor-faktor yang dapat menimbulkan kecenderungan menciptakan senjangan dalam anggaran. Faktor-faktor tersebut diantaranya partisipasi anggaran, Nurfaizah (2007) menyatakan bahwa partisipasi dalam penyusunan anggaran merupakan partisipasi aparat pemerintah daerah yang mengarah pada seberapa besar tingkat keterlibatan aparat pemerintah daerah dalam menyusun anggaran serta pelaksanaannya untuk mencapai target anggaran. Partisipasi diperlukan dalam penyusunan anggaran, hal ini dikarenakan bawahan lebih mengetahui kondisi unit organisasinya. Apabila seluruh anggota organisasi dapat berpartisipasi serta terlibat dalam menentukan langkah untuk menentukan tujuan dalam penganggaran, maka tujuan yang terdapat dalam anggaran akan mudah terealisasi. Individu yang terlibat dalam proses penganggaran dapat mempengaruhi senjangan dalam anggaran, hal tersebut dinilai dari sejauh mana individu tersebut mampu menentukan prioritas antara kepentingan sendiri atau bekerja demi kepentingan organisasi. Individu yang terlibat dalam penyusunan anggaran haruslah seseorang yang memiliki kapasitas yang baik. Berkaitan dengan proses penganggaran, maka individu yang memiliki cukup pengetahuan akan mampu mengalokasikan sumberdaya secara optimal, dengan demikian dapat memperkecil resiko senjangan dalam anggaran (Venusita, 2009).

Kapasitas individu menurut Tresnayani dan Gayatri (2016: 1411) merupakan sebuah penilaian teknis atas apa yang dilakukan oleh individu untuk melaksanakan sesuatu yang dalam hal ini untuk meningkatkan produktifitas kerja. Selain kapasitas yang dimiliki, self esteem yang dimiliki oleh Individu yang terlibat dalam proses penganggaran juga mempengaruhi senjangan dalam anggaran. Robbins dan Judge (2007) menyatakan bahwa self esteem merupakan suatu tingkat individu dari perasaan suka atau tidak suka atas dirinya sendiri dan sejauh mana mereka berpikir bahwa mereka layak atau tidak layak sebagai pribadi mereka. Orang yang memiliki self esteem tinggi cenderung memandang diri mereka sendiri sebagai seorang yang penting, sedangkan orang dengan self esteem rendah merasa kurang baik dengan dirinya. Nugrahaini dan Sugiri (2004) mengemukakan bahwa kaitannya dengan senjangan anggaran yaitu seseorang dengan self esteem yang rendah cenderung lebih tinggi dalam menciptakan senjangan anggaran.

Proses penyusunan anggaran juga diperlukan kejelasan terhadap sasaran aggaran. Agar anggaran lebih produktif, perlu adanya penetapan tujuan secara spesifik. Penetapan anggaran yang spesifik akan mendorong karyawan untuk melakukan yang terbaik bagi tercapainya tujuan yang dikehendaki sehingga berpengaruh pada peningkatan kinerja. 
Sasaran atau disebut dengan target dalam konteks pemerintah daerah merupakan hasil yang di inginkan dari suatu program atau keluaran yang diharapkan dari suatu kegiatan (Permendagri Nomor 21 Tahun 2011 pasal 1 ayat 43). Kecamatan Petanahan merupakan salah satu kecamatan yang terletak di Kabupaten Kebumen yang terdiri dari 21 desa. Berdasarkan data ikhtisar laporan pertanggungjawaban realisasi pelaksanaan APBDes tahun anggaran 2018, Kecamatan Petanahan terindikasi mengalami senjangan anggaran. Hal ini terlihat dari tabel realisasi anggaran yang menunjukkan terdapat 7 desa di Kecamatan Petanahan mengalami senjangan anggaran yang cukup tinggi. Berikut prosentase laporan realisasi APBDes 7 desa yang mengalami senjangan anggaran cukup tinggi tahun 2018.

Tabel 1. Laporan realisasi APBDes tahun 2018

\begin{tabular}{lcc}
\hline Nama Desa & Persentase Anggaran Pendapatan & Persentase Anggaran Belanja \\
\hline Karanggadung & $100,00 \%$ & $79,11 \%$ \\
Tegalretno & $100,61 \%$ & $99,92 \%$ \\
Kewangunan & $100,09 \%$ & $98,51 \%$ \\
Karangduwur & $100,02 \%$ & $99,69 \%$ \\
Nampudadi & $100,20 \%$ & $95,10 \%$ \\
Sidomulyo & $100,36 \%$ & $91,22 \%$ \\
Banjarwinangun & $100,11 \%$ & $98,80 \%$ \\
\hline
\end{tabular}

Sumber : DISPERMADES Kabupaten Kebumen (2018)

Berdasarkan data prosentase laporan realisasi APBDes pada tabel diatas, mencerminkan indikasi adanya senjangan anggaran desa di Kecamatan Petanahan. Indikasi adanya senjangan anggaran ini dapat dilihat dari realisasi anggaran pendapatan yang lebih tinggi daripada jumlah anggaran yang ditargetkan sebelumnya. Disisi lain realisasi belanja lebih kecil dari jumlah anggaran belanja yang ditetapkan sebelumnya. Hal ini diduga dilakukan agar kinerja pemerintah desa terlihat bagus, karena pemerintah desa terlihat mampu menghemat belanja. Dari 21 desa yang ada, hanya terdapat satu desa yang mampu merealisasikan anggaran belanja 100\%. Sedangkan sisanya yaitu sebanyak 13 desa belum mampu untuk melakukan penyerapan anggaran dengan baik. Hal ini menunjukkan bahwa di Kecamatan Petanahan masih sedikit desa yang mampu untuk menetapkan target lebih realistis dan lebih baik.

\section{Kajian Teori dan Telaah Literatur}

\section{Teori keagenan}

Teori keagenan merupakan teori yang mempelajari hubungan atau keterkaitan pihak-pihak yang memiliki jalinan hubungan fungsional dan struktural, yaitu prinsipal dan agen. Menurut Jansen dan Meckling (1976) dalam Basyir (2016) teori keagenan adalah konsep yang menjelaskan hubungan kontraktual antara prinsipal dan agen, yaitu antara dua orang atau lebih individu, kelompok atau organisasi. Pada penelitian ini teori agensi bertujuan untuk menjelaskan hubungan antara atasan dan bawahan dalam proses penyusunan anggaran terutama saat bawahan menargetkan anggaran.

\section{Partisipasi anggaran}

Menurut Dharmanegara (2010:19) partisipasi penyusunan anggaran adalah proses pengambilan keputusan secara bersama oleh dua bagian atau lebih pihak dimana keputusan 
tersebut akan memiliki dampak masa depan terhadap mereka yang membuatnya, dengan kata lain pekerja dan manajer tingkat bawah memiliki suara dalam prosesnya. Ikhsan (2007:174) menyatakan bahwa partisipasi dalam proses penyusunan anggaran adalah tingkat seberapa jauh keterlibatan dan pengaruh individu dalam penyusunan anggaran.

Partisipasi anggaran merupakan suatu metode dalam penganggaran dengan tujuan untuk memperoleh anggaran yang objektif, dalam partisipasi penganggaran semua tingkat manajemen terlibat dalam penyusunan dan pengembangan anggaran. Mardiasmo (2018:226) menyatakan bahwa partisipasi bawahan yang lebih tinggi dalam proses penganggaran mengarah pada senjangan anggaran yang lebih besar, hal ini dikarenakan tersedianya akses yang lebih besar terhadap informasi daerah pada saat proses pengambilan keputusan terkait dengan penganggaran. Pradani dan Erawati (2016) juga mengemukakan bahwa bawahan yang berpartisipasi dalam penyusunan anggaran akan cenderung menimbulkan senjangan anggaran (budgetary slack) untuk menghindari resiko ketidakpastian masa mendatang

\section{$\boldsymbol{H}_{\mathbf{1}}$ : Partisipasi anggaran berpengaruh positif terhadap senjangan anggaran.}

\section{Kapasitas individu}

Tresnayani dan Gayatri (2016: 1411) menyatakan bahwa kapasitas individu atau kemampuan merupakan sebuah penilaian teknis atas apa yang dilakukan oleh individu untuk melaksanakan sesuatu yang dalam hal ini untuk meningkatkan produktivitas dalam bekerja. Individu yang berkualitas adalah individu yang memiliki pengetahuan. Maskun (2009) menyatakan apabila pengetahuan yang dimiliki oleh individu penyusun anggaran tidak cukup, akan mengakibatkan individu tersebut mengalami kesulitan dalam melaksanakan tugas pokok dan fungsinya. Kurangnya pengetahuan yang dimiliki oleh seorang individu akan memperbesar kecenderungan untuk melakukan senjangan terhadap anggaran.

Kapasitas yang dimiliki oleh seorang individu, terbentuk dari proses pendidikan baik melalui pendidikan formal, pendidikan non formal, maupun pengalaman. Pendidikan formal diperoleh melalui sekolah, sedangkan pendidikan non formal diperoleh melalui pelatihanpelatihan keuangan. Pendidikan formal dan non formal merupakan investasi sumber daya manusia yang dapat meningkatkan kemampuan dan ketrampilan kerja, sehingga dapat meningkatkan kinerja seseorang. Pada proses penganggaran, individu yang memiliki pengetahuan yang cukup akan mampu mengalokasikan sumber daya yang ada secara optimal, mampu menghadapi dan mengantisipasi ketidakpastian lingkungan terutama isu mengenai senjangan anggaran, hal tersebut dapat meminimalisir terjadinya senjangan dalam anggaran.

Organisasi sektor publik dalam era otonomi daerah perlu untuk menyiapkan tenaga kerja atau aparatur pemerintah yang mempunyai kemampuan yang baik. Aparatur pemerintah daerah diharapkan dapat meningkatkan profesionalitas birokrasi dalam memberikan pelayanan publik. Lestara et al (2016) menyatakan bahwa berkaitan dengan proses penyusunan anggaran, pengetahuan individu yang tinggi dapat meminimalisir tingkat senjangan anggaran. Namun dalam prakteknya, semakin tinggi kapasitas individu justru memunculkan anggapan bahwa senjangan anggaran semakin meningkat

$\boldsymbol{H}_{2}$ : Kapasitas individu berpengaruh negatif terhadap senjangan anggaran 


\section{Self esteem}

Robbins dan Judge (2007:102) mendefinisikan self esteem sebagai suatu tingkat individu dari perasaan suka atau tidak suka atas dirinya sendiri dan sejauh mana mereka berpikir bahwa mereka layak atau tidak layak sebagai pribadi mereka. Self esteem merupakan keyakinan nilai diri sendiri berdasarkan evaluasi secara keseluruhan. Self esteem berkaitan dengan bagaimana seseorang menilai dirinya akan mempengaruhi perilakunya dalam kehidupan sehari-hari. Khaira (2018) menyatakan bahwa self esteem adalah penilaian yang dibuat oleh seseorang dan biasanya bersifat tetap tentang dirinya. Hal tersebut menyatakan sifat setuju atau tidak setuju, dan menunjukkan sejauh mana orang tersebut menganggap bahwa dirinya mampu, berarti, sukses, dan bahagia. Self esteem merupakan aspek kepribadian yang merupakan kunci terpenting dalam pembentukan perilaku seseorang, karena hal ini berpengaruh pada proses berpikir, tingkat emosi, keputusan yang diambil bahkan pada nilainilai dan tujuan hidup seseorang, Gunarsa (2009).

Berdasarkan uraian yang dikemukakan diatas, maka dapat disimpulkan bahwa self esteem menggambarkan bahwa sejauh mana individu tersebut menilai dirinya sebagai orang yang memiliki kemampuan, keberanian, berharga, dan kompeten. Individu dengan self esteem yang tinggi menunjukkan perilaku menerima dirinya apa adanya, percaya diri, puas dengan kemampuan dan karakter diri. Individu dengan self esteem yang rendah akan menunjukkan penghargaan buruk terhadap dirinya sehingga tidak mampu menyesuaikan dirinya dengan lingkungan sosial.

Menurut Sari dan Putra (2017) dalam kaitannya dengan senjangan anggaran pada proses penyusunan secara partisipatif, seorang penyusun anggaran dengan self esteem yang rendah akan cenderung menciptakan senjangan anggaran lebih tinggi. Manajer penyusun anggaran dengan self esteem tinggi akan termotivasi untuk melakukan pekerjaannya dengan baik untuk menjaga konsistensi hasil evaluasi dirinya dari kondisi asimetri yang mereka peroleh.

$\boldsymbol{H}_{3}$ : Self-esteem berpengaruh negatif terhadap senjangan anggaran.

\section{Kejelasan sasaran anggaran}

Karakteristik dalam anggaran salah satunya adalah kejelasan sasaran anggaran. Sasaran anggaran dalam konteks pemerintah daerah tercakup dalam rencana strategik daerah dan program pembangunan daerah. Adanya sasaran yang jelas akan memudahkan individu dalam menyusun target-target anggaran. Selanjutnya target-target dalam anggaran yang disusun akan sesuai dengan sasaran yang hendak dicapai oleh organisasi.

Menurut Sari dan Putra (2017), kejelasan sasaran anggaran merupakan sejauh mana anggaran ditetapkan secara jelas dan spesifik dengan tujuan agar anggaran tersebut dapat dimengerti oleh orang yang bertanggung jawab atas pencapaian anggaran tersebut. Agar anggaran yang disusun lebih produktif, perlu adanya penetapan tujuan secara spesifik. Penetapan tujuan dengan spesifik akan mendorong karyawan untuk melakukan yang terbaik bagi pencapaian tujuan yang dikehendaki sehingga berimplikasi pada peningkatan kinerja. Pada konteks pemerintah daerah, sasaran atau disebut dengan target merupakan hasil yang diinginkan dari suatu program keluaran yang diharapkan dari suatu kegiatan (Permendagri Nomor 21 Tahun 2011 pasal 1 ayat 43).

Keluaran yang dimaksud dalam pasal 1 ayat 43 adalah barang atau jasa yang dihasilkan oleh kegiatan yang dilaksanakan untuk mendukung pencapaian sasaran dan tujuan dalam program dan kebijakan. Hasil yang dimaksud adalah segala sesuatu yang mencerminkan 
berfungsinya keluaran dari kegiatan-kegiatan dalam suatu program. Adanya sasaran anggaran yang jelas, maka akan mempermudah dalam mempertanggung jawabkan keberhasilan dan kegagalan dari suatu pelaksanaan tugas yang telah dilaksanakan dalam rangka untuk mencapai tujuan-tujuan dan sasaran-sasaran yang sebelumnya telah ditetapkan (Pitasari, 2014). Pencapaian target anggaran akan lebih mudah tercapai apabila pihak penyusun anggaran mengerti mengenai rencana yang akan dilaksanakan

$\boldsymbol{H}_{4}$ : Kejelasan sasaran anggaran berpengaruh positif terhadap senjangan anggaran.

\section{Metode Penelitian}

\section{Populasi dan sampel}

Penelitian ini dilakukan di desa yang berada di Kecamatan Petanahan yang berjumlah 21 desa. Populasi dalam penelitian ini adalah seluruh aparat pemerintah desa Kecamatan Petanahan. Sedangkan sampel dalam penelitian ini adalah aparat pemerintah desa di Kecamatan Petanahan yang terlibat dalam proses penyusunan dan. pelaksanaan anggaran diantaranya: Kepala Desa, Kaur Keuangan, Kaur Perencanaan, dan Sekertaris Desa. Instrumen yang digunakan dalam penelitian ini adalah kuisioner dengan pertanyaan yang berkaitan dengan partisipasi anggaran, kapasitas individu, self esteem, kejelasan sasaran anggaran, terhadap senjangan anggaran. Skala pengukuran yang digunakan dalam penelitian ini adalah skala likert 5 . Teknik yang digunakan yaitu statistik deskriptif, uji kualitas data yang terdiri dari uji validitas dan uji reliabilitas. Uji asumsi klasik yang terdiri dari uji normalitas, uji heteroskedastisitas. Uji hipotesis menggunakan uji koefisien determinasi $\left(\mathrm{R}^{2}\right)$, uji t parsial, uji simultan, dan analisis regresi linear berganda.

Kuisioner yang disebarkan dalam penelitian ini sebanyak 84 kuisioner dan kuisioner kembali sebanyak 74 kuisioner, sedangkan kuisioner yang dapat diolah lebih lanjut sebanyak 43 kuisioner. Hipotesis dalam penelitian ini dianalisis menggunakan analisis regresi linear berganda dengan menggunakan software SPSS 23. Sebelum uji hipotesis dilakukan, data penelitian terlebih dahulu diuji menggunakan uji asumsi klasik.

\section{Hasil dan Pembahasan}

\section{Uji validitas}

Uji validitas dalam penelitian ini digunakan untuk memastikan apakah kuisioner yang akan dipakai untuk untuk mengukur variabel kuisioner valid atau tidak. Berdasarkan uji yang telah dilakukan maka dapat diketahui bahwa nilai $r$ hitung lebih besar dari $r$ tabel 0,3008 , dengan nilai sig sebesar 0,000 $<0,05$ sehingga dapat disimpulkan bahwa semua instrumen pertanyaan masing -masing variabel dalam penelitian dinyatakan valid.

\section{Uji reliabilitas}

Uji reliabilitas digunakan untuk mengukur suatu kuisioner yang merupakan indikator dari variabel. Suatu kuisioner dikatakan reliabel apabila jawaban seseorang terhadap pertanyaan adalah konsisten atau stabil dari waktu ke waktu. Uji reliabilitas data dilakukan dengan metode cronbach's alpha yakni suatu instrumen dikatakan reliabel apabila memiliki 
koefisien keandalan reliabilitas sebesar 0,60 atau lebih. Hasil uji reliabilitas yang telah dilakukan menunjukkan bahwa:

Tabel 2. Hasil uji reliabilitas

\begin{tabular}{llcc}
\hline \multicolumn{1}{c}{ No } & \multicolumn{1}{c}{ Variabel } & $\begin{array}{c}\text { Cronbach's } \\
\text { Alpha }\end{array}$ & Keterangan \\
\hline 1. & Partisipasi Anggaran & 0,689 & Reliabel \\
2. & Kapasitas Individu & 0,661 & Reliabel \\
3. & Self Esteem & 0,670 & Reliabel \\
4. & Kejelasan Sasaran Anggaran & 0,756 & Reliabel \\
5. & Senjangan Anggaran & 0,689 & Reliabel \\
\hline
\end{tabular}

Sumber: Data diolah (2020)

\section{Uji normalitas data}

Uji normalitas digunakan untuk mengetahui apakah distribusi data dalam suatu variabel yang digunakan dalam suatu penelitian layak untuk dianalisis. Data dikatakan berdistribusi normal apabila memiliki nilai koefisie Asymp sig (2 tailed) lebih besar dari 0,05. Berdasarkan hasil uji normalitas dapat dilihat nilai dari koefisien asymp sig (2-tailed) sebesar 0,061 maka dapat disimpulkan bahwa data dalam penelitian berdistribusinormal.

Tabel 3. Uji normalitas one-sample kolmogorov-smirnov test

\begin{tabular}{llr}
\hline & & \multicolumn{2}{c}{$\begin{array}{c}\text { Unstandardized } \\
\text { Residual }\end{array}$} \\
\hline $\mathrm{N}$ Normal Parameters & & 43 \\
& Mean &, 0000000 \\
Most Extreme Differences & Std. Deviation & 1,87491570 \\
& Absolute &, 131 \\
& Positive &, 131 \\
Test Statistic & Negative &,- 098 \\
Asymp. Sig. (2-tailed) & &, 131 \\
\hline a. Test distribution is Normal. & &, $061^{\mathrm{c}}$ \\
$\quad$ Sumber: Data Diolah, 2020 & &
\end{tabular}

Sumber: Data diolah (2020)

\section{Uji multikolinearitas}

Uji multikolinearitas bertujuan untuk menguji apakah pada model regresi ditemukan adanya korelasi antar variabel bebas. Berdasarkan aturan Variance Inflation Factor (FIV) dan tolerance hasil uji multikolinearitas dalam penelitian ini tidak terjadi multikolinearitas antar variabel bebas. Hal ini diketahui dari nilai FIV yang diperoleh masing-masing variabel lebih kecil dari 10 dan nilai tolerance lebih besar dari 0,10. 
Tabel 4. Uji multikolinearitas

\begin{tabular}{cccr}
\hline & \multicolumn{2}{c}{ Collinearity Statistics } \\
\cline { 2 - 4 } Model & Tolerance & VIF \\
\hline 1 & (Constant) & & \\
& X1 &, 598 & 1,673 \\
X2 &, 739 & 1,353 \\
X3 &, 740 & 1,351 \\
\multicolumn{2}{r}{ X4 } &, 604 & 1,657 \\
\hline \multicolumn{2}{l}{ a. Dependent Variable: Y1 }
\end{tabular}

Sumber: Data diolah (2020)

\section{Uji heteroskedastisitas}

Uji heteroskedastisitas bertujuan untuk menguji apakah dalam model regresi terjadi ketidaksamaan varian dari residual suatu pengamatan ke pengamatan yang lain. Uji heteroskedastisitas dilakukan dengan menggunakan uji glejser. Berdasarkan uji glejser yang telah dilakukan dapat diketahui bahwa untuk variabel partisipasi anggaran (X1) mempunyai nilai signifikansi sebesar 0,807 >0,05, variabel kapasitas individu (X2) mempunyai nilai signifikan sebesar 0,909 >0,05, variabel self esteem (X3) memiliki nilai signifikansi sebesar $0,923>0,05$, dan variabel kejelasan sasaran anggaran (X4) memiliki nilai signifikansi sebesar $0,152>0,05$. Hasil tersebut menunjukkan bahwa data dalam penelitian tidak mengalami heteroskedastisitas dikarenakan nilai signifikansi masing-masing variabel lebih besar dari 0,05 .

Tabel 5. Uji heteroskedastisitas

\begin{tabular}{|c|c|c|c|c|c|}
\hline \multirow[b]{2}{*}{ Model } & \multicolumn{2}{|c|}{$\begin{array}{l}\text { Unstandardized } \\
\text { Coefficients }\end{array}$} & $\begin{array}{l}\text { Standardized } \\
\text { Coefficients }\end{array}$ & \multirow[b]{2}{*}{$\mathrm{T}$} & \multirow[b]{2}{*}{ Sig. } \\
\hline & B & $\begin{array}{l}\text { Std. } \\
\text { Error }\end{array}$ & Beta & & \\
\hline 1 (Constant) & 5,307 & 2,512 & & 2,113 &, 041 \\
\hline $\mathrm{X} 1$ &,- 025 & 102 &,- 049 &,- 246 & 807 \\
\hline $\mathrm{X} 2$ & ,012 & 107 & ,021 & 115 & 909 \\
\hline $\mathrm{X} 3$ & ,006 & ,063 & ,017 & ,097 & ,923 \\
\hline $\mathrm{X} 4$ &,- 158 & 108 &,- 291 & $-1,463$ & 152 \\
\hline
\end{tabular}

A. Dependent Variable: ABS_RES

Sumber: Data diolah (2020)

\section{Hasil uji hipotesis}

\section{Uji koefisien determinasi}

Koefisien determinasi digunakan untuk mengukur seberapa jauh kemampuan model dalam menerangkan variasi variabel dependen. Berdasarkan hasil penelitian yang dilakukan dapat diketahui bbahwa nilali koefisien determinasi dalam penelitian ini sebesar 32\% yang berarti bahwa variabel partisipasi anggaran, kapasitas individu, self esteem, kejelasan sasaran anggaran hanya mampu menjelaskan sebesar $32 \%$ pengaruh terhadap senjangan anggaran sedangkan sisanya $68 \%$ dipengaruhi oleh faktor lain yang tidak diteliti dalam penelitian ini. 
Tabel 6. Uji koefisien determinasi

\begin{tabular}{lcrrr}
\hline Model & R & R Square & $\begin{array}{c}\text { Adjusted R } \\
\text { Square }\end{array}$ & $\begin{array}{c}\text { Std. Error of the } \\
\text { Estimate }\end{array}$ \\
\hline $1 \quad, 620^{a}$ &, 385 &, 320 & 1,971 \\
\hline a. Predictors: (Constant), X4, X3, X2, X1 & \\
b. Dependent Variable: Y1 & & \\
Sumber: Data diolah (2020)
\end{tabular}

\section{Analisis regresi linear berganda}

Analisis regresi linear berganda digunakan untuk untuk mengukur intensitas hubungan dua variabel atau lebih. Untuk mengetahui pengaruh antara Partisipasi Anggaran (X1), Kapasitas Individu (X2), Self Esteem (X3), Kejelasan Sasaran Anggaran (X4), tehadap Senjangan Anggaran (Y) dilakukan dengan menggunakan persamaan regresi sebagai berikut:

Tabel 7. Analisis regresi linear berganda

\begin{tabular}{|c|c|c|c|c|c|}
\hline \multirow[b]{2}{*}{ Model } & \multicolumn{2}{|c|}{ Unstandardized Coefficients } & $\begin{array}{c}\text { Standardized } \\
\text { Coefficients }\end{array}$ & \multirow[b]{2}{*}{$\mathrm{T}$} & \multirow[b]{2}{*}{ Sig. } \\
\hline & $\mathrm{B}$ & Std. Error & Beta & & \\
\hline 1 (Constant) & 11,614 & 3,657 & & 3,175 & 003 \\
\hline X1 & 315, & 149, & 350 & 2,124 & ,040 \\
\hline $\mathrm{X} 2$ &,- 203 & 155 &,- 193 & $-1,305$ & ,200 \\
\hline X3 &,- 050 & 091 &,- 081 &,- 547 & ,587 \\
\hline X4 & ,452 & 158 & ,469 & 2,862 & ,007 \\
\hline
\end{tabular}

A. Dependent Variable: Y1

Sumber: Data diolah (2020)

\section{Uji t parsial}

Uji statistik $t$ digunakan untuk menunjukkan seberapa jauh pengaruh suatu variabel penjelas atau independen secara individual dalam menerangkan variasi variabel dependen. Berdasarkan hasil uji parsial diketahui bahwa:

Tabel 8. Uji t parsial

\begin{tabular}{|c|c|c|c|c|c|}
\hline \multirow[b]{2}{*}{ Model } & \multicolumn{2}{|c|}{$\begin{array}{c}\text { Unstandardized } \\
\text { Coefficients }\end{array}$} & \multirow{2}{*}{$\begin{array}{c}\text { Standardized } \\
\text { Coefficients } \\
\text { Beta }\end{array}$} & \multirow[b]{2}{*}{$\mathrm{t}$} & \multirow[b]{2}{*}{ Sig. } \\
\hline & B & Std. Error & & & \\
\hline 1 (Constant) & 11,614 & 3,657 & & 3,175 & ,003 \\
\hline $\mathrm{X} 1$ & ,315 & 149 & ,350 & 2,124 & ,040 \\
\hline $\mathrm{X} 2$ &,- 203 & 155 &,- 193 & $-1,305$ & 200 \\
\hline $\mathrm{X} 3$ &,- 050 & ,091 &,- 081 &,- 547 & ,587 \\
\hline X4 & ,452 & 158, & 469, & 2,862 & ,007, \\
\hline
\end{tabular}

a. Dependent Variable: Y1

Sumber: Data diolah (2020) 


\section{Pembahasan}

\section{Pengaruh partisipasi anggaran terhadap senjangan anggaran}

Hipotesis pertama yang diajukan dalam penelitian ini adalah partisipasi anggaran berpengaruh positif terhadap senjangan anggaran. Berdasarkan hasil analisis dari uji $\mathrm{t}$ pada variabel partisipasi anggaran (X1), menunjukkan bahwa nilai signifikansinya sebesar 0,039< 0,05 dari hasil tersebut diperoleh $t$ hitung sebesar 2,124 > dari t tabel 2.024. Maka dapat disimpulkan bahwa hipotesis pertama diterima, yaitu partisipasi anggaran berpengaruh positif terhadap senjangan anggaran desa di Kecamatan Petanahan.

Hasil penelitian ini menunjukan bahwa semakin tinggi tingkat partisipasi anggaran maka senjangan anggaran yang terjadi juga semakin meningkat. Bawahan akan berusaha agar anggaran yang mereka susun mudah tercapai dan menurunkan resiko yang mungkin terjadi di masa mendatang dengan cara memberikan informasi bias kepada atasan yang berakibat pada minimnya informasi yang diperoleh atasan. Hasil penelitian ini sejalan dengan penelitian yang dilakukan oleh Pertiwi dan Mahardhika (2019), Pradani dan Erawati (2016), Basyir (2016) yang menyatakan bahwa partisipasi anggaran berpengaruh positif dan signifikan terhadap senjangan anggaran. Penelitian ini tidak sejalan dengan penelitian yang dilakukan oleh Pamungkas et al (2014), Tresnayani dan Gayatri (2016) yang menyatakan bahwa partisipasi anggaran berpengaruh negatif terhadap senjangan anggaran.

\section{Pengaruh kapasitas individu terhadap senjangan anggaran}

Hipotesis kedua yang diajukan dalam penelitian ini adalah kapasitas individu berpengaruh negatif terhadap senjangan anggaran. Berdasarkan hasil analisis pada uji $\mathrm{t}$ variabel kapasitas individu (X2) diketahui bahwa nilai signifikansi dari kapasitas individu yaitu 0,198>0,05 dengan nilai thitung $-1,310$ (negatif) $<\mathrm{t}$ tabel 2.024 maka dapat disimpulkan bahwa hipotesis kedua ditolak yang artinya kapasitas individu tidak berpengaruh terhadap senjangan anggaran. Hal tersebut menunjukkan bahwa tinggi rendahnya kapasitas yang dimiliki oleh individu penyusun anggaran tidak berpengaruh terhadap senjangan anggaran. Hipotesis tidak diterima dikarenakan meskipun terdapat responen yang menjawab tidak setuju (2), namun kebannyakan menjawab netral (3) dan setuju (4) selebihnya menjawab sangat setuju (5). Berdasarkan data tersebut maka dapat disimpulkan bahwa dalam penelitian ini responden hanya memiliki tingkat pengetahuan, pelatihan dan pengalaman sedang (menengah) dalam melakukan penyusunan anggaran.

Kapasitas individu terbentuk dari pengalaman dan kemampuan, sehingga tidak dapat digunakan sebagai tolak ukur kencenderungan seseorang dalam melakukan senjangan anggaran. Hasil penelitian ini sejalan dengan penelitian yang dilakukan oleh Usman (2016), Irawati dan Mutiara (2018) yang menyatakan bahwa kapasitas individu tidak berpengaruh terhadap senjangan anggaran. Penelitian ini tidak sejalan dengan penelitian yang dilakukan oleh Pradani dan Erawati (2016) yang menyatakan bahwa kapasitas individu berpengaruh negatif terhadap senjangan anggaran.

\section{Pengaruh self esteem terhadap senjangan anggaran}

Hipotesis ketiga yang diajukan dalam penelitian ini adalah self esteem (X3) berpengaruh negatif terhadap senjangan anggaran. Berdasarkan hasil analisis pada uji $\mathrm{t}$ dapat diketahui bahwa nilai signifikansi variabel self esteem adalah 0,574>0,05 dan hasil dari t hitung $-0,567$ (negatif) kurang dari $\mathrm{t}$ tabel 2.024, maka dapat disimpulkan bahwa hipotesis ketiga ditolak 
yang berarti bahwa self esteem tidak berpengaruh terhadap senjangan anggaran. Hal ini menunjukkan bahwa tinggi rendahnya self esteem yang dimiliki perangkat desa tidak berpengaruh terhadap senjangan anggaran. Hipotesis tidak diterima dikarenakan berdasarkan data yang diperoleh meskipun terdapat responden yang yang menjawab tidak setuju (2) namun jumlahnya sedikit, sedangkan sebagian besar responden memilih jawaban netral (3) dan setuju (4) selebihnya menjawab sangat setuju (5), sehingga dapat disimpulkan bahwa perangkat desa di Kecamatan Petanahan memiliki tingkat kepercayaan diri yang sedang dalam melakukan penyusunan anggaran. Penyebab lain self esteem tidak berpengaruh terhadap senjangan anggaran yaitu faktor-faktor pembentuk self esteem diantaranya genetik, lingkungan dan pengalaman membuat self esteem tidak mampu mengungkapkan secara pasti kecenderungan seseorang dalam melakukan senjangan anggaran. Hasil penelitian ini sejalan dengan penelitian yang dilakukan oleh Krisnawati dan Suartana (2007), Usman (2016) yang menyatakan bahwa self esteem tidak berpengaruh terhadap senjangan anggaran. Penelitian ini tidak sejalan dengan penelitian yang dilakukan oleh Pamungkas et al (2014), Yasa et al (2017), Netra dan Damayanti (2017), Agustin et al (2019), yang menyatakan bahwa self esteem berpengaruh neggatif terhadap senjangan anggaran.

\section{Pengaruh kejelasan sasaran anggaran terhadap senjangan anggaran}

Hipotesis keempat yang diajukan dalam penelitian ini adalah kejelasan sasaran anggaran (X4) berpengaruh positif terhadap senjangan anggaran. Berdasarkan hasil dari uji $t$ menunjukkan bahwa nilai signifikansi variabel kejelasan sasaran anggaran adalah 0,007 < 0,05 dan nilai thitung 2,870 > t tabel 2,024, maka dapat disimpulkan bahwa hipotesis keempat diterima yaitu variabel kejelasan sasaran anggaran berpengaruh positif terhadap senjangan anggaran. Hasil tersebut menunjukkan bahwa semakin jelas sasaran yang ada maka senjangan anggaran yang terjadi juga semakin meningkat. Anggaran seringkali disusun sebelum periode berlangsung sehingga anggaran menjadi kaku dan rawan terjadi senjangan, baik senjangan kurang maupun senjangan lebih. Hasil penelitiaan ini sejalan dengan penelitian yang dilakukan oleh Fauziah (2014), Bintara dan Putri (2014) yang menyatakan bahwa partisipasi anggaran berpengaruh positif signifikan terhadap senjangan anggaran. Penelitian ini tidak sejalan dengan penelitian yang dilakukan oleh Tresnayani dan Gayatri (2017), Erina dan Suartana (2016) yang menyatakan bahwa kejelasan sasaran anggarab berpengaruh negatif terhadap senjangan anggaran.

\section{Penutup dan Saran}

Berdasarkan hasil penelitian dan pembahasan yang telah dilakukan maka dapat diambil kesimpulan sebagai berikut:

a. Variabel Partisipasi Anggaran berpengaruh positif terhadap senjangan anggaran desa yang terjadi di Kecamatan Petanahan dengan nilai signifikansi pada uji t sebesar 0,040 lebih kecil dari nilai signifikansi 0,05. Hal ini berarti bahwa apabila partisipasi dari partisipan penyusun anggaran tinggi maka senjangan anggaran desa yang terjadi di Kecamatan Petanahan juga meningkat.

b. Variabel Kapasitas Individu tidak berpengaruh terhadap senjangan anggaran desa di Kecamatan Petanahan ditunjukkan dengan nilai signifikansi pada uji t sebesar 0,200 lebih besar dari nilai signifikansi 0,05.Hal ini berarti bahwa kenaikan maupun 
penurunan kapasitas yang dimiliki oleh individu penyusun anggaran tidak mempengaruhi senjangan anggaran desa yang terjadi di Kecamatan Petanahan

c. Variabel self esteem tidak berpengaruh terhadap senjangan anggaran desa di Kecamatan Petanahan ditunjukkan dengan nilai signifikansi pada uji t sebesar 0,587 lebih besar dari nilai signifikansi 0,05 . Hal ini berarti bahwa kenaikan maupun penurunan self esteem yang dimiliki oleh individu penyusun anggaran tidak mempengaruhi terjadinya senjangan anggaran desa di Kecamatan Petanahan.

d. Variabel Kejelasan sasaran anggaran berpengaruh positif terhadap senjangan anggaran desa di Kecamatan Petanahan dengan nilai signifikansi pada uji t sebesar 0,007 lebih kecil dari nilai signifikansi 0,05. Hal tersebut menunjukkan bahwa apabila kejelasan kejelasan sasaran anggaran meningkat maka senjangan anggaran yang terjadi di Kecamatan Petanahan juga meningkat.

e. Berdasarkan hasil analisis regresi linear berganda diperoleh hasil uji koefesien determinasi (R2) sebesar 0,32 artinya 32\% variabel senjangan anggaran dipengaruhi oleh partisipasi anggaran, kapasitas individu, self esteem, dan kejelasan anggaran. Sedangkan sisanya 68\% (100-32) dipengaruhi oleh variabel lain yang tidak diteliti dalam penelitian ini.

\section{Saran}

Saran yang dapat diberikan berdasarkan kesimpulan dan hasil penelitian adalah:

a. Berdasarkan hasil dari penelitian yang telah dilakukan, maka OPD Kecamatan Petanahan diharapkan untuk meningkatkan pelatihan mengenai penganggaran supaya individu penyusun anggaran mempuyai kemampuan yang memadai serta meningkatkan kepercayaan diri saat penyusunan anggaran berlangsung, dengan tujuan agar senjangan anggaran dapat diminimalisir.

b. Untuk peneliti selanjutnya disarankan untuk menambah wilayah penelitian serta memasukkan variabel lain yang diduga mempengaruhi senjangan anggaran seperti penekanan anggaran, budaya organisasi, job relevant information, asimetri informasi dan komitmen organisasi. Sehingga dapat diketahui cara untuk menciptakan kinerja yang lebih baik serta mengurangi terjadinya senjangan anggaran

\section{Referensi}

Agustin, E., Hidayati, N., \& Mahsuni, A. W. (2019). Pengaruh Self Esteem, Skema Pemberian Insentif, dan Tanggung Jawab Personal Terhadap Budgetary Slack. Jurnal Ilmiah Riset Akuntansi, 8(02), 81-92.

Ambarini, E., \& Mispiyanti, M. (2020). Pengaruh Budget Emphasis, Self Esteem, dan Partisipasi Anggaran Terhadap Budgetary Slack Pada OPD Pemerintah Kabupaten Kebumen. Jurnal Ilmiah Mahasiswa Manajemen, Bisnis Dan Akuntansi (JIMMBA), 2(1), 19. https://doi.org/10.32639/jimmba.v2i1.434

Anthony, R.N., \& Govindarajan, V. (2007). Control Manajemen System. Boston: MC Graw-Hill Co.

Ardinasari, I. F. (2017). Kapasitas Individu, Budaya Organisasi, Asimetri Informasi Pada Penyusunan Anggaran Partisipatif Terhadap Budgetary Slack. Skripsi. Fakultas Ekonomi. Universitas Negri Yogyakarta. 
Arif, B., Muchlis, \& Iskandar. (2002). Akuntansi Pemerintahan. Jakarta: Salemba Empat.

Arthaswadaya. A. (2015). Pengaruh Informasi Asimetri terhadap Budgetary Slack dengan Self Esteem Sebagai Variabel Permoderasi: Studi Esperimen dalam Konteks Penganggaran Partisipatif. Skripsi. Program S1 Pendidikan Akuntansi Fakultas Ilmu Ekonomi. Universitas Negri Yogyakarta.

Bahri, S. (2018). Metodologi Penelitian Bisnis. Yogyakarta: Andi.

Bastian, I. (2017). Akuntansi Manajemen Sektor Publik. Jakarta: Salemba Empat. Jakarta.

Basyir, A. A. (2017). Pengaruh partisipasi anggaran, informasi asimetri, dan kapasitas individu terhadap budgetary slack pada skpd pemerintah kota samarinda. Akuntabel, 13(2), 82-102.

Biantara, A. A. A., \& Putri, I. A. A. D. (2014). Pengaruh Kejelasan Sasaran Anggaran, Etika, dan Kepercayaan Diri pada Senjangan Anggaran. E-Jurnal Akuntansi, 9(2), 385-391.

Dharmanegara, I. B. A. (2010). Penganggaran Perusahaan Teori dari Aplikasi. Denpasar: Graha Ilmu.

Erina, N. P. D., \& Suartana, W. (2016). Pengaruh partisipasi penganggaran, penekanan anggaran, kapasitas individu, dan kejelasan sasaran anggaran pada senjangan anggaran. E-Jurnal Akuntansi, 15(2), 973-1000.

Ghozali, I. (2006). Aplikasi Multivariate Dengan Program SPSS. Edisi Keempat. Semarang: Penerbit Universitas Diponegoro.

Ghozali, I. (2018). Aplikasi Analisis Multivariate: Dengan Program IBM SPSS 25. Edisi Kesembilan. Cetakan Kesembilan. Semarang: Badan Penerbit Universitas Diponegoro.

Gunarsa, S. D. (2009). Dari Anak Sampai Usia Lanjut: Bunga Rampai Psikologi Perkembangan. Jakarta: Gunung Mulia.

Ikhsan, A. (2007). Pengaruh Partisipasi Anggaran terhadap Senjangan Anggaran dengan Menggunakan Lima Variabel Pemoderasi. Simposium Nasional Akuntansi X, 1-27.

Ikhsan, A., \& Ishak, M. (2005). Akuntansi Keperilakuan. Jakarta: Salemba Empat.

Indarti, I., Anton, A., \& Wati, B. E. S. (2017). Pengaruh Partisipasi Penyusunan Anggaran terhadap Kinerja Instansi Pemerintah dengan Komitmen Organisasi sebagai Variabel Moderating. Jurnal Ilmiah Aset, 19(1), 37-50.

Irawati, A., \& Mutiara, A. (2019). Faktor-Faktor yang Mempengaruhi Senjangan Anggaran. Jurnal Ilmiah ESAI, 12(2), 62-70.

Krisnawati, I. A., \& Suartana, I. W. (2007). Pengaruh Kepercayaan Diri dalam Penyusunan Anggaran.Jurnal Bisnis dan Manajemen, 7(1), 111-120.

Lestara, I. G. E. Y. S., Herawati, N. T., AK, S., \& Purnamawati, I. G. A. (2017). Pengaruh Asimetri Informasi, Penekanan Anggaran Dan Kapasitas Individu Terhadap Senjangan Anggaran Dengan Locus Of Control Sebagai Variabel Moderasi (Studi Empiris Pada 
Satuan Kerja Perangkat Daerah Berupa Dinas Kabupaten Gianyar). JIMAT (Jurnal Ilmiah Mahasiswa Akuntansi) Undiksha, 7(1).

Mardiasmo. (2018). Otonomi E Manajemen Keuangan Daerah. Andi. Yogyakarta.

Maskun, A. (2009). Analisis Faktor Etika, Budaya Birokrasi, Tekanan Sosial dan Kapasitas Individu terhadap Budgetary Slack (Senjangan Anggaran)(Kajian Perilaku Eksekutif Dalam Proses Penyusunan Anggaran Di Badan Koordinator Wilayah II Jawa Timur). Jurnal Aplikasi Manajemen, 7(1), 162-172.

Nafarin, M. (2013). Penganggaran Perusahaan. Edisi ketiga. Cetakan kedua. Buku 1. Jakarta: Salemba Empat.

Nurfaizah, N., \& Mildawati, T. (2007). Pengaruh Penyusunan Partisipasi Anggaran Terhadap Kinerja Manajerial dengan Variabel Permoderasi Gaya Kepemimpinan dan Komitmen Organisasi Pada Pemkot Surabaya. Jurnal Akuntansi dan Manajemen Bisnis Sektor Publik (JAMBPS), 3(3).

Pamungkas, I. M. B. W., ADIPUTRA, I. M. P., \& Sulindawati, N. L. G. E. (2014). Pengaruh partisipasi anggaran, informasi asimetri, budaya organisasi, kompleksitas tugas, reputasi, etika dan self esteem terhadap budgetary slack (studi pada satuan kerja perangkat daerah kabupaten jembrana). JIMAT (Jurnal Ilmiah Mahasiswa Akuntansi) Undiksha, 2(1).

Pamungkas, I. M. B. W., ADIPUTRA, I. M. P., SE, S., Si, M., \& Sulindawati, N. L. G. E. (2014). Pengaruh partisipasi anggaran, informasi asimetri, budaya organisasi, kompleksitas tugas, reputasi, etika dan self esteem terhadap budgetary slack (studi pada satuan kerja perangkat daerah kabupaten jembrana). JIMAT (Jurnal Ilmiah Mahasiswa Akuntansi) Undiksha, 2(1).

Pertiwi, D., \& Mahardhika, A. S. (2019). Anteseden Senjangan Anggaran Desa Di Kabupaten Kebumen. Muhammadiyah Riau Accounting and Business Journal, 1(1), 039-045.

Pitasari, K. K. A., Sulindawati, N. L. G. E., Atmadja, A. T., \& SE, A. (2014). Pengaruh Kejelasan Sasaran Anggaran dan Keadilan Prosedural terhadap Sejangan Anggaran (Budgetary Slack) pada SKPD berupa Dinas di Pemerintah Kabupaten Klungkung. JIMAT (Jurnal Ilmiah Mahasiswa Akuntansi) Undiksha, 2(1).

Putra, D. (2013). Pengaruh akuntabilitas publik dan kejelasan sasaran anggaran terhadap kinerja manajerial Satuan kerja perangkat daerah (Studi Empiris pada Satuan Kerja Perangkat Daerah Kota Padang). Jurnal Akuntansi, 1(1).

Robbins, S. P., \& Judge. (2007). Perilaku Organisasi. Jakarta: Salemba Empat.

Sari, N. L. E. Y., \& Putra, I. N. W. A. (2017). Kapasitas individu, self esteem, komitmen organisasi, dan penekanan anggaran memoderasi partisipasi penganggaran pada senjangan anggaran. E-Jurnal Akuntansi, 1189-1218.

Suartana, I.W. 2010. Akuntansi Keperilakuan Teori dan Implementasi. ANDI. Yogyakarta.

Sugiyono. (2010). Metode Penelitian Kuantitatif, Kualitatif, dan RED. Cetakan ke-11. Bandung: Alfabeta. 
Supriyono, R. A. (2005). Pengaruh Komitmen Organisasi, Keinginan Sosial, dan Asimetri Informasi terhadap Hubungan Antara Partisipasi Penganggaran dengan Kinerja Manajer. Jurnal Ekonomi dan Bisnis Indonesia, 20(2005).

Syahrir, A. D. (2017). Pengaruh Penganggaran Partisipatif Terhadap Budget Slack dengan Sikap sebagai Variabel Moderating. InFestasi (Jurnal Bisnis dan Akuntansi), 13(1), 243252.

Tresnayani, L. G. A., \& Gayatri. (2017) .Pengaruh Partisipasi Anggaran, Asimetri Informasi, Kapasitas Individu, dan Kejelasan Sasara Anggaran terhadap Potensi Terjadinya Budgetary Slack. E-Jurnal Akuntansi Universitas Udayana, 16(2), 1405-1532.

Usman, F. K. (2016). Pengaruh Etika, Self Esteem dan Kapasitas Individu terhadap Budgetary Slack (Studi pada Mahasiswa Akuntansi Universitas Bengkulu. Skripsi. Universitas Bengkulu. Bengkulu.

Yasa, I. G. M., Diatmika, I. P. G., \& Prayudi, M. A. (2018). Pengaruh Partisipasi Anggaran, Penekanan Anggaran, Kejelasan Sasaran Anggaran, dan Self Esteem Terhadap Senjangan Anggaran Desa di Kecamatan Kubutambahan. JIMAT (Jurnal Ilmiah Mahasiswa Akuntansi) Undiksha, 8(2). 